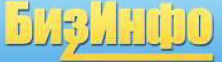

Часопис из области економије менаџмента и информатике

Година 2016, волумен 7, број 1, стр. 1-11

\section{Bi $17 /$. n.}

Journal of Economics, Management and Informatics

Year 2016, Volume 7, Number 1, pp. 1-11

Оригиналан научни рад/ Original scientific paper

УДК/UDC: 005.953.2:005.22

316.472 .3

DOI: $10.5937 /$ bizinfo1601001K

\title{
AN APPROACH TO PERSONNEL SELECTION BASED ON SWARA AND WASPAS METHODS
}

\section{ПРИСТУП ИЗБОРУ КАДРОВА ЗАСНОВАН НА SWАRА И WASPAS МЕТОДАМА}

\author{
Darjan Karabašević ${ }^{1}$ \\ John Naisbitt University Belgrade, Faculty of Management Zaječar \\ Dragiša Stanujkić \\ John Naisbitt University Belgrade, Faculty of Management Zaječar \\ Snežana Urošević \\ University of Belgrade, Technical Faculty in Bor \\ Mlađan Maksimović \\ John Naisbitt University Belgrade, Faculty of Management Zaječar
}

Abstract: Human resource management is consisted of all activities that are aimed at ensuring continuous development, satisfying the needs of employees, motivation and retention of employees within the company along with achievement of their goals in an effective manner. Development plan of human resource management in the company is created in accordance with the strategic objectives of the company. Human resource management in the company also has its most important integrative component that is reflected in attracting and retaining employees who possess certain skills and competencies. Therefore, process of recruitment and selection occupies a very important role in the management of human resources. This manuscript propose one approach to problem of personnel selection based on the use of

\footnotetext{
${ }^{1}$ darjankarabasevic@gmail.com
} 
SWARA and WASPAS method. In order to demonstrate efficiency and applicability of the proposed approach, a numerical example is conducted. Key words: HRM, recruitment and selection, MCDM, SWARA, WASPAS

Сажетак: Менациент људских ресурса се састоји од свих активности које су усмерене на обезбеђивање непрестаног развоја, задовољења потреба запослених, мотивачије и задржавања запослених у оквиуру компаније уз остварење юихових ииљева и максималну ефикасност. План развоја менаимента ьудских ресурса у компанији креира се у складу са стратешким ииљевима компаније. Менацмент ьудских ресурса у компанији такође има и своју најзначајнију интегративну компоненту која се огледа у привлачењу и задржавању запослених који поседују одређене вештине и компетениије. Стога, прочес регрутаиије и селекиије заузима веома значајану улогу у менаименту ьудских ресурса. У раду се предлаже један приступ проблему избора кадрова заснован на употреби SWARA и WASPAS метода. $У$ ииљу демонстрирања ефикасности и примењливости предложеног приступа спроведен је нумерички пример.

Кључне речи: МљР, регрутација и селекиија, MCDM, SWARA, WASPAS

\section{INTRODUCTION}

Employees, as one significant resource in the organization, were initially engaged managers and staffing departments. Considering the fact that the over time competition is amplified, and competitive race has become more global. Companies have started to more and more efforts and resources to invest in human resources, because they recognize that exactly investments in people, i.e. employees, the organization can bring a competitive advantage. The transition is from personnel department to the management of human resources, the united efforts of companies and their commitment to invest in human capital development (Sheehan, 2005).

Confirmation that human resource management is becoming an important management function in the organization, in their research emphasizes Mihajlović et al. (2012), which also state that the strategy of human resources management helps "management" to establish priorities and to define the vision of the model of human resource management in the organization.

Bearing in mind that human resources are essential strategic component in achieving competitiveness, Redman and Wilkinson (Redman, Wilkinson, 2008) state that it is imperative that the strategy of development of human resources must be in line with the business policy and strategy of the organization. Whereas, implementation of the strategy should take into account the people as a resource, so it is imperative for human resources to be 
involved in the implementation of the business culture, which is adopted by business strategy of the company. Jovanović Božinov et al. (2004) points out that in the modern business environment one of the forms of the struggle between companies becomes a struggle for creative professionals, proven and trusted leaders, educated and talented people.

Problem of selecting candidates in the recruitment and selection process, i.e. selection of the best candidate among several candidates / alternatives is a complex problem that belongs to multi-criteria decision-making (MCDM) and which is usually accompanied by vagueness, imprecision and subjectivity in some segments. Therefore, one part of the literature is devoted to the use of MCDM methods for the selection of personnel such as: SWARA-ARAS approach for personnel selection proposed by Karabašević et al. (2015), SWARA-MULTIMOORA approach for personnel selection proposed by Karabašević et al. (2015), personnel selection using ANP and fuzzy DEA approaches (Lin, 2010) and so on.

Therefore, the paper is organized as follows: Section 1 gives a introduction, Section 2 highlights importance of recruitment and selection, Section 3 presents SWARA method, while in Section 4 WASPAS method is presented. In Section 5 numerical example is presented and finally conclusions are given at the end of the paper.

\section{THE ROLE AND IMPORTANCE OF THE PROCESS OF RECRUITMENT AND SELECTION OF PERSONNEL}

As previously stated people i.e. human resources are one of the main strategic resources that companies rely today, and to whom is paying special attention in order to achieve performance and competitiveness on the market.

Selection of quality personnel and, above all, competent employees who can resist to the all business challenges of today, represents a problem which every company is taking seriously, because the further development of company depends on the employees who work there, i.e. on their competence, motivation and commitment.

Urošević and Sajfert (2012) recruiting (recruitment) define as a process that involves attracting qualified candidates in a number that will allow the organization to choose the best candidates in order to fill the vacancies. While, Dowling et al. (2008) emphasizes that recruitment is a process of searching and finding potential candidates for a certain number of jobs in order to select the most suitable candidate for a specific job. In simple terms, recruitment is the process of finding and hiring the people needed to the organization. 
The process that logically continues after the recruitment process is a process of personnel selection. Griffin (2011) points out that the selection process represents collection of information from the applicants in order to predict their success at work and future work engagement, which will then select the best among them, in order to employ the most successful candidates. Armstrong (2009) underlines that the selection represents the process of deciding which the applicants should be placed on job positions. Therefore, selection is defined as the process of gathering information for the purpose of evaluating candidates and making decision to employ a specific candidate for certain jobs.

Since the selection of personnel is an essential factor in human resource management, it is important to state that a significant number of studies and research to problem of personnel selection is approaching by using tools such as psychometric tests, cognitive tests, personality tests, intelligence tests, structured interviews, assessment centers of competence / potential etc. (Wright et al., 1989; Morgeson et al., 2007). Braun and Warner (2002) state that in certain circumstances it is not always possible to apply the above mentioned methods. In their study they point out claims and reasons for limited use of psychometric testing and assessment centers, such as follow-up costs and questionable cross-cultural validity.

The process of recruitment and selection of personnel in most general sense, can be presented as a process which strives to obtain personnel with specific competences that certain position require.

\section{SWARA METHOD}

The Step-wise Weight Assessment Ratio Analysis (SWARA) method was developed by Kersuliene et al. (2010) in 2010 and until now it is applied for solving various problems such as: a rational dispute resolution (Kersuliene et al. 2010), architect selection (Kersuliene and Turskis, 2011), personnel selection (Zolfani and Banihashemi, 2014, Karabasevic et al., 2015), packaging design selection (Stanujkic et al., 2015), and so forth.

The computational procedure for the criteria weights determination using SWARA method, based on Kersuliene et al. (2010) can be accurately shown as follows: 


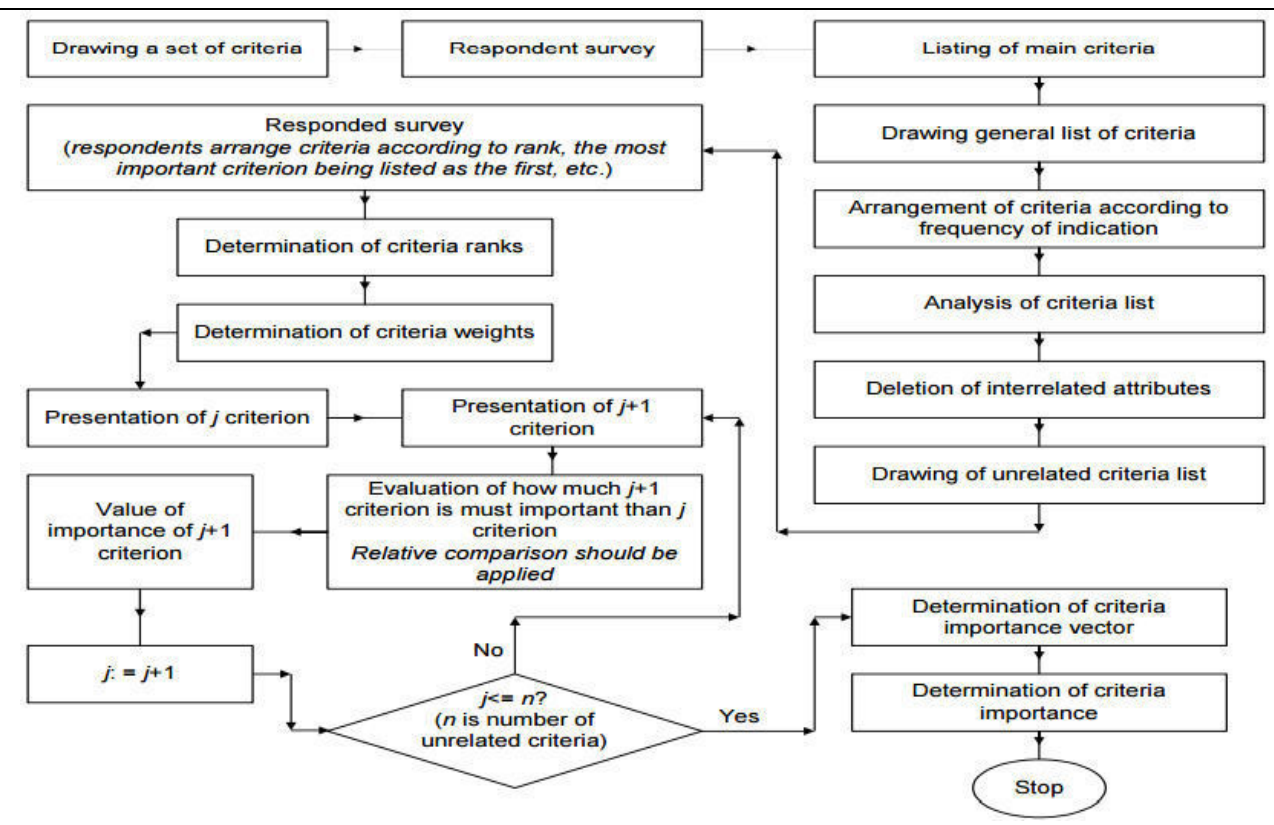

Figure 1. Determining relative weights of the criteria based on the application of the SWARA method (Kersuliene and Turskis, 2011)

\section{WASPAS METHOD}

Weighted aggregates sum product assessment (WASPAS) method was proposed by Zavadskas et al. (2012). The WASPAS method represents a unique combination of two well-known MCDM approaches: weighted sum (WS) method and weighted product (WP) method.

WASPAS method is used to solve different problems, such as: in manufacturing decision making (Chakraborty, Zavadskas, 2014), evaluation of fasades' alternative (Zavadskas et al., 2013a) and so on.

The computational procedure of WASPAS method can be precisely presented as follows:

Step 1. Determine the optimal performance rating for each criterion. In this step, the optimal performance ratings are calculated as follows:

$x_{0 j}=\left\{\begin{array}{ll}\max _{i} x_{i j} ; & j \in \Omega_{\max } \\ \min _{i} x_{i j} ; & j \in \Omega_{\text {min }}\end{array}\right.$,

where $x_{0 j}$ denotes the optimal performance rating of $j$-th criterion, $\Omega_{\text {max }}$ denotes the benefit criteria, i.e. the higher the values are, the better it is; 
and $\Omega_{\min }$ denotes the set of cost criteria, i.e. the lower the values are, the better it is, $m$ denotes number of alternatives; $i=0,1, \ldots, m$; and $n$ denotes number of criteria, $, j=0,1, \ldots, n$.

Step 2. Construct the normalized decision matrix. The normalized performance ratings are calculated as follows:

$$
r_{i j}=\left\{\begin{array}{ll}
\frac{x_{i j}}{x_{0 j}} ; & j \in \Omega_{\max } \\
\frac{x_{0 j}}{x_{i j}} ; & j \in \Omega_{\min }
\end{array},\right.
$$

where $r_{i j}$ denotes the normalized performance rating of $i$-th alternative in relation to the $j$-th criterion.

Step 3. Calculate the relative importance of $i$-th alternative, based on WS method. The relative importance of $i$-th alternative, based on WS method, is calculated as follows:

$$
Q_{i}^{(1)}=\sum_{j=1}^{n} w_{j} r_{i j} \text {, }
$$

where $Q_{i}^{(1)}$ denotes the relative importance of $i$-th alternative in relation to the $j$-th criterion, based on WS method.

Step 4. Calculate the relative importance of $i$-th alternative, based on WP method (Madić, 2014). The relative importance of $i$-th alternative, based on WP method, is calculated as follows:

$$
Q_{i}^{(2)}=\prod_{j=1}^{n} r_{i j}^{w_{j}}
$$

where $Q_{i}^{(2)}$ denotes the relative importance of $i$-th alternative in relation to the $j$-th criterion, , based on WP method.

Step 5. Calculate total relative importance, for each alternative. The total relative importance, or more precisely the joint generalized criterion of weighted aggregation of additive and multiplicative methods (Zavadskas et al., 2013a, 2013b) is calculated as follows:

$Q_{i}=0.5 Q_{i}^{(1)}+0.5 Q_{i}^{(2)}=0.5 \sum_{j=1}^{n} w_{j} r_{i j}+0.5 \prod_{j=1}^{n} r_{i j}{ }^{w_{j}}$ 
In order to have increased ranking accuracy and effectiveness of the decision making process, in WASPAS method, a more generalized equation for determining the total relative importance of $i$-th alternative is developed as below (Šaparauskas et al., 2011; Zavadskas et al., 2012):

$$
Q_{i}=\lambda Q_{i}^{(1)}+(1-\lambda) Q_{i}^{(2)}=\lambda \sum_{j=1}^{n} w_{j} r_{i j}+(1-\lambda) \prod_{j=1}^{n} r_{i j}{ }^{w_{j}}
$$

\section{A NUMERICAL EXAMPLE}

In order to demonstrate applicability and efficiency of the proposed approach, in this section numerical example is conducted. Numerical example is based on the criteria that are used by Karabasevic et al. (2016) in their research for the selection of Sales Manager. Application of the proposed SWARAWASPAS approach can be accurately presented through following steps:

Step 1. Determine the weights of the evaluation criteria based on SWARA method. The team of three experts was formed. Set of evaluation criteria with resulting group weights that will be used for evaluation of four candidates are shown in table 1.

Table 1. The set of competencies for the position of Sales Manager

\begin{tabular}{|l|l|l|}
\hline & Criteria & $\boldsymbol{w}_{j}$ \\
\hline$C_{1}$ & Interview preparedness & 0.29 \\
\hline$C_{2}$ & Relevant work experience & 0.22 \\
\hline$C_{3}$ & Education & 0.17 \\
\hline$C_{4}$ & Interpersonal skills & 0.12 \\
\hline$C_{5}$ & $\begin{array}{l}\text { Communication and } \\
\text { presentation skills }\end{array}$ & 0.09 \\
\hline$C_{6}$ & Computer skills & 0.06 \\
\hline$C_{7}$ & Foreign languages & 0.05 \\
\hline & & 1.00 \\
\hline
\end{tabular}

Step 2. Evaluate the candidates in relation to the evaluation criteria. Based on the ratings obtained from the three experts, group ratings are calculated as follows:

$x_{i j}=\left(\prod_{k=1}^{3} x_{i j}^{k}\right)^{1 / 3}$, 
The group ratings of the four evaluated candidates obtained from the three human resource experts are shown in Table 2.

Table 2. The initial decision-making matrix

\begin{tabular}{|c|c|c|c|c|c|c|c|}
\hline $\begin{array}{c}\text { Criteria } \\
\text { Candidates }\end{array}$ & $\boldsymbol{C}_{\mathbf{1}}$ & $\boldsymbol{C}_{\mathbf{2}}$ & $\boldsymbol{C}_{\mathbf{3}}$ & $\boldsymbol{C}_{\mathbf{4}}$ & $\boldsymbol{C}_{\mathbf{5}}$ & $\boldsymbol{C}_{\mathbf{6}}$ & $\boldsymbol{C}_{\boldsymbol{7}}$ \\
\hline$w_{\mathrm{j}}$ & 0.29 & 0.22 & 0.17 & 0.12 & 0.09 & 0.06 & 0.05 \\
\hline$A_{1}$ & 4.67 & 5.00 & 4.67 & 4.67 & 4.33 & 5.00 & 4.67 \\
\hline$A_{2}$ & 3.33 & 3.00 & 4.00 & 2.67 & 4.00 & 3.67 & 3.67 \\
\hline$A_{3}$ & 4.00 & 4.00 & 4.00 & 3.00 & 4.00 & 4.00 & 3.33 \\
\hline$A_{4}$ & 3.33 & 3.33 & 3.67 & 3.33 & 3.00 & 3.67 & 2.33 \\
\hline
\end{tabular}

Step 3. Construct normalized decision matrix. In the next step, using Eq. (2), a normalized decision matrix has been formed. The normalized decision matrix, as well as the weights of the criteria are shown in Table 3.

Table 3. The normalized decision matrix and the weight of the criteria

\begin{tabular}{|c|c|c|c|c|c|c|c|}
\hline $\begin{array}{c}\text { Criteria } \\
\text { Candidates }\end{array}$ & $\boldsymbol{C}_{\mathbf{1}}$ & $\boldsymbol{C}_{\mathbf{2}}$ & $\boldsymbol{C}_{\mathbf{3}}$ & $\boldsymbol{C}_{\mathbf{4}}$ & $\boldsymbol{C}_{\mathbf{5}}$ & $\boldsymbol{C}_{\mathbf{6}}$ & $\boldsymbol{C}_{\boldsymbol{7}}$ \\
\hline$w_{j}$ & 0.29 & 0.22 & 0.17 & 0.12 & 0.09 & 0.06 & 0.05 \\
\hline$A_{1}$ & 1.00 & 1.07 & 1.00 & 1.00 & 0.93 & 1.07 & 1.00 \\
\hline$A_{2}$ & 0.71 & 0.64 & 0.86 & 0.57 & 0.86 & 0.79 & 0.79 \\
\hline$A_{3}$ & 0.86 & 0.86 & 0.86 & 0.64 & 0.86 & 0.86 & 0.71 \\
\hline$A_{4}$ & 0.71 & 0.71 & 0.79 & 0.71 & 0.64 & 0.79 & 0.50 \\
\hline
\end{tabular}

Step 4. Calculate the relative importances of the evaluated alternatives. The relative importances of the evaluated alternatives, based on weighted sum (WS) method and weighted product (WP) are shown in table Table 4.

Table 4. The relative and total importance of the alternatives

\begin{tabular}{|c|c|c|c|c|}
\hline & $Q_{i}^{(1)}$ & $Q_{i}^{(2)}$ & $Q_{i}$ & Rank \\
\hline$A_{1}$ & 0.51 & 0.09 & 0.59 & $\mathbf{1}$ \\
\hline$A_{2}$ & 0.36 & 0.06 & 0.42 & $\mathbf{3}$ \\
\hline$A_{3}$ & 0.41 & 0.07 & 0.48 & $\mathbf{2}$ \\
\hline$A_{4}$ & 0.36 & 0.06 & 0.42 & $\mathbf{4}$ \\
\hline
\end{tabular}

Data from the table 4. show us that candidate designated as $A_{l}$ has the highest total importance in terms of evaluated criteria.

\section{CONCLUSIONS}

Human resource management often includes different activities that have impact on increasing the efficiency and effectiveness on employee operation 
and work and with continuous directing of employees towards achieving company goals. Finding and employment of quality personnel is a key activity of management of human resources in ensuring adequate human potential. Therefore, this manuscript is aimed at providing efficient approach to personnel selection. From the conducted numerical example it can be seen that the proposed SWARA-WASPAS approach is adaptive, applicable and easy to use for the selection of personnel. Also, candidate designated as $A_{l}$ is the best ranked in terms of evaluated competencies and criteria. With some modifications proposed SWARA-WASPAS approach can be used in other areas as well.

\section{REFERENCES}

1. Armstrong, M. 2009. Handbook of Human Resource Management Practice. 11th Edition. London: Kogan Page.

2. Braun, W. H., Warner, M. 2002. Strategic human resource management in western multinationals in China: The differentiation of practices across different ownership forms. Personnel Review, 31(5), pp. 553-579.

3. Chakraborty, S., Zavadskas, E. K. 2014. Applications of WASPAS method in manufacturing decision making. Informatica, 25(1), pp. 120.

4. Dowling, P. J., Festing, M., Engle, A. D. 2008. International Human Resource Management - Managing people in a multinational context. London: Cengage Learning.

5. Griffin, R. W. 2011. Management. Mason: South-Western Cengage Learning.

6. Hashemkhani Zolfani, S, Banihashemi, S. S. A. 2014. Personnel selection based on a novel model of game theory and MCDM approaches. in Proc. of 8th International Scientific Conference "Business and Management 2014", 15-16 May 2014, Vilnius, Lithuania, 191-198.

7. Jovanović Božinov, M., Kulić, Ž., Cvetkovski, T. 2004. Menadžment ljudskih resursa. Beograd: Megatrend Univerzitet.

8. Karabašević, D., Stanujkić, D., Urošević, S. 2015. The MCDM Model for Personnel Selection Based on SWARA and ARAS Methods. Management časopis za teoriju i praksu menadžmenta, 77, pp. 43-52.

9. Karabasevic, D., Stanujkic, D., Urosevic, S., Maksimovic, M. 2015. Selection of Candidates in the Mining Industry Based on the Application of the SWARA and the MULTIMOORA Methods. Acta Montanistica Slovaca, 20(2), pp. 116-124.

10. Karabasevic, D., Zavadskas, E. K., Turskis, Z., Stanujkic, D. 2016. The framework for the selection of personnel based on the SWARA 
and ARAS methods under uncertainties. Informatica, 27(1), pp. 4965 .

11. Keršulienè, V., Turskis, Z. 2011. Integrated fuzzy multiple criteria decision making model for architect selection. Technological and Economic Development of Economy, 17(4), pp. 645-666.

12. Keršulienè, V., Zavadskas, E. K., Turskis, Z. 2010. Selection of rational dispute resolution method by applying new step-wise weight assessment ratio analysis (SWARA). Journal of Business Economics and Management, 11(2), pp. 243-258.

13. Lin, H. T. 2010. Personnel selection using analytic network process and fuzzy data envelopment analysis approaches. Computers \& Industrial Engineering, 59(4), pp. 937-944.

14. Madić, M., Gecevska, V., Radovanović, M., Petković, D. 2014. Multicriteria economic analysis of machining processes using the WASPAS method. Journal of Production Engineering, 17(2), pp. 1-6.

15. Mihajlović, D., Ilić, B., Maksimović, M. 2012. Human resources management - contributing to successful business operations of a company. 2nd International Symposium on Natural Resources Management, Zaječar, Serbia.

16. Morgeson, F. P., Campion, M. A., Dipboye, R. L., Hollenbeck, J. R. Murphy, K., Schmitt, N. 2007. Reconsidering the use of personality tests in personnel selection contexts, Personnel Psychology, 60(3), pp. 683-729.

17. Redman, T., Wilkinson, A. 2008. Conteporary Human Resource Management. England: Prentice Hall, Harlow.

18. Šaparauskas, J., Zavadskas, E. K, Turskis, Z. 2011. Selection of facade's alternatives of commercial and public buildings based on multiple criteria. International Journal of Strategic Property Management, 15(2), pp. 189-203.

19. Sheehan, C. 2005. A model for HRM strategic integration. Personnel Review, 34(2), pp. 192-209.

20. Stanujkic, D., Karabasevic, D., Zavadskas, E. K. 2015. A framework for the selection of a packaging design based on the SWARA method. Inzinerine Ekonomika - Engineering Economics, 26(2), pp. 181-187.

21. Urošević, S. Sajfert, Z. 2012. Menadžment ljudskih resursa. Beograd: Don Vas.

22. Wright, P. M., Lichtenfels, P. A., Pursell, E. D. 1989. The structured interview: Additional studies and a meta-analysis. Journal of Occupational and Organizational Psychology, 62(3), pp. 191-199.

23. Zavadskas, E. K., Antucheviciene, J., Saparauskas, J., Turskis, Z. 2013a. Multi-criteria assessment of facades' alternatives: peculiarities of ranking methodology. Procedia Engineering, 57, pp. 107-112.

24. Zavadskas, E. K., Antucheviciene, J., Saparauskas, J., Turskis, Z. 2013b. MCDM methods WASPAS and MULTIMOORA: verification 
AN APPROACH TO PERSONNEL SELECTION BASED ON SWARA AND WASPAS METHODS

of robustness of methods when assessing alternative solutions. Economic Computation and Economic Cybernetics Studies and Research, 47(2), pp. 5-20.

25. Zavadskas, E. K., Turskis, Z., Antucheviciene, J., Zakarevicius, A. 2012. Optimization of Weighted Aggregated Sum Product Assessment. Electronics and Electrical engineering, 6(122), pp. 3-6.

26. Zavadskas, E. K., Turskis, Z., Antucheviciene, J., Zakarevicius, A. 2012. Optimization of Weighted Aggregated Sum Product Assessment. Electronics and Electrical engineering, 6(122), pp. 3-6.

Рад је примљен: 10.04.2016.

Прихваћен за објављивање: 14.04.2016.

Received: 10 April 2016

Accepted: 14 April 2016 